\title{
R.E.D.-RROM (RESTORE THE EUROPEAN DIMENSION OF RROMANI): THE FIRST COMPREHENSIVE IT LEARNING TOOL FOR THE UNIFIED RROMANI LANGUAGE
}

\begin{abstract}
R.E.D.-RROM je транснационални интернет портал намењен за школску наставу ромског као циљног језика, створен од стране Smallcodes-a ca најновијим информационим и комуникационим технологијама (ICT), као први свеобухватни алат информационих технологија (IT) за ромски језик. Портал је подељен на три макро-целине: увод, курс језика, ромска култура. Цео курс у основи је намењен студентима универзитета, али је осмишљен на свакодневном вокабулару, тако да га било која особа са средњом школом може савладати. Крајњи циљ портала је да покаже да се ромски језик може користити као формални језик и језик књижевности и да се може сматрати као један језик. Стога, ученици могу комбиновати слушање различитих дијалеката и титлове на овом порталу како би се навикли на дијалекатске варијације и приметили да могу да разумеју све дијалекте. Културни одељак обухвата разноврсне теме као што су књижевност, историја, лингвистика, европска комуникација, које су све представљене на ромском језику.
\end{abstract}

Кључне речи: R.E.D.-RROM, ромски језик, Smallcodes, ICT технологије, IT учење.

\section{Introduction}

R.E.D.-RROM (www.red-rrom.com) is a transnational web portal designed for school teaching of Rromani as the target language, using 16 other navigation languages as a medium of instruction. Several e-learning systems for Rromani such as dictionaries on line or language lessons exist so far but none of them covers the real dialectal diversity of Rromani and this fact can endanger the existence of the Rromani language. We should notice the existence of locally forgotten vocabulary that is the bigger reason for the lack of mutual understanding, but serious cultural projects and didactic efforts could help reverse this process. "Dialect is not an issue, oblivion is the issue". 
R.E.D.-RROM, as the first comprehensive IT learning tool for the unified Rromani language, has been created by Smallcodes (www.smallcodes.com) with the most recent ICT technologies. Smallcodes is a cooperative project for minority language revaluation through technology and has developed a linguistic e-platform for all "small languages", with specific attention to the internal variability which is often typical of minority or endangered languages.

In fact, the final aim of the portal is to demonstrate to a broad audience that Rromani language can be used as a formal and literary exchange language. This issue concerns all minority languages but it is perhaps far more critical with Rromani, because of the widespread paternalistic approach towards Rromani people, which promotes assimilation at all costs. To surmount this issue, the culture section on this portal covers diverse topics such as Rromani literature, history, history of Rromani music, ethnology, linguistics, and European communication, that are all presented in Rromani language.

Moreover, the portal supports the conviction that Rromani can still be considered a single language at present, against the common belief that modern European Rroms speak numerous corrupted dialects, no longer mutually comprehensible. To disprove this belief, the R.E.D.-RROM portal contains audios and videos in which students can combine the dialect of hearing and the dialect of subtitles, in order to get used to the dialectal variation and to notice they can understand all dialects while actively using their own.

We will illustrate this process in detail and show how it has been achieved with the support of some specific ICT technologies.

\section{The Rromani language (i rromani ćhib)}

Rromani is the language of six to eight million users (according to the calculation method), out of a total Rromani population of ten to twelve million in Europe and three million across the Atlantic. It is spoken on a daily basis by about five and a half million Rroms. Mutual understanding is possible between good speakers of various regions in so far as everyday life is the topic, but it becomes rather difficult when more knowledge about sophisticated subjects is required.

Since the Rroms originate from North-central India, Rromani belongs to the Indo-Aryan family and is very close to Indian languages in vocabulary and grammatical structure (especially the nominal group system). 
Rromani language has more than 800 Indian roots, about 200 Greek ones, 70 Persian ones, 35 Armenian ones and a handful of Georgian or Ossetic origin. The words including these roots are used by the entirety of Rromani speakers regardless of their geographic distribution. They were integrated into Rromani before the Rroms' arrival in Europe.

More recently dozens of local borrowings have been added, especially Slavic and Romanian, but also German and Hungarian - mainly words of modern life. This is the main reason which gives the impression of a large number of dialects in Rromani, although in reality only a few lexical sectors, true enough very conspicuous but nonetheless superficial sectors, present substantial differences between Rromani vernaculars. Rromani language is divided into four main dialects and we underline that vernaculars should not be confused with dialects. Dialects have comparatively sharp limits, whereas vernaculars are in fracturing continuum, and therefore not numerable.

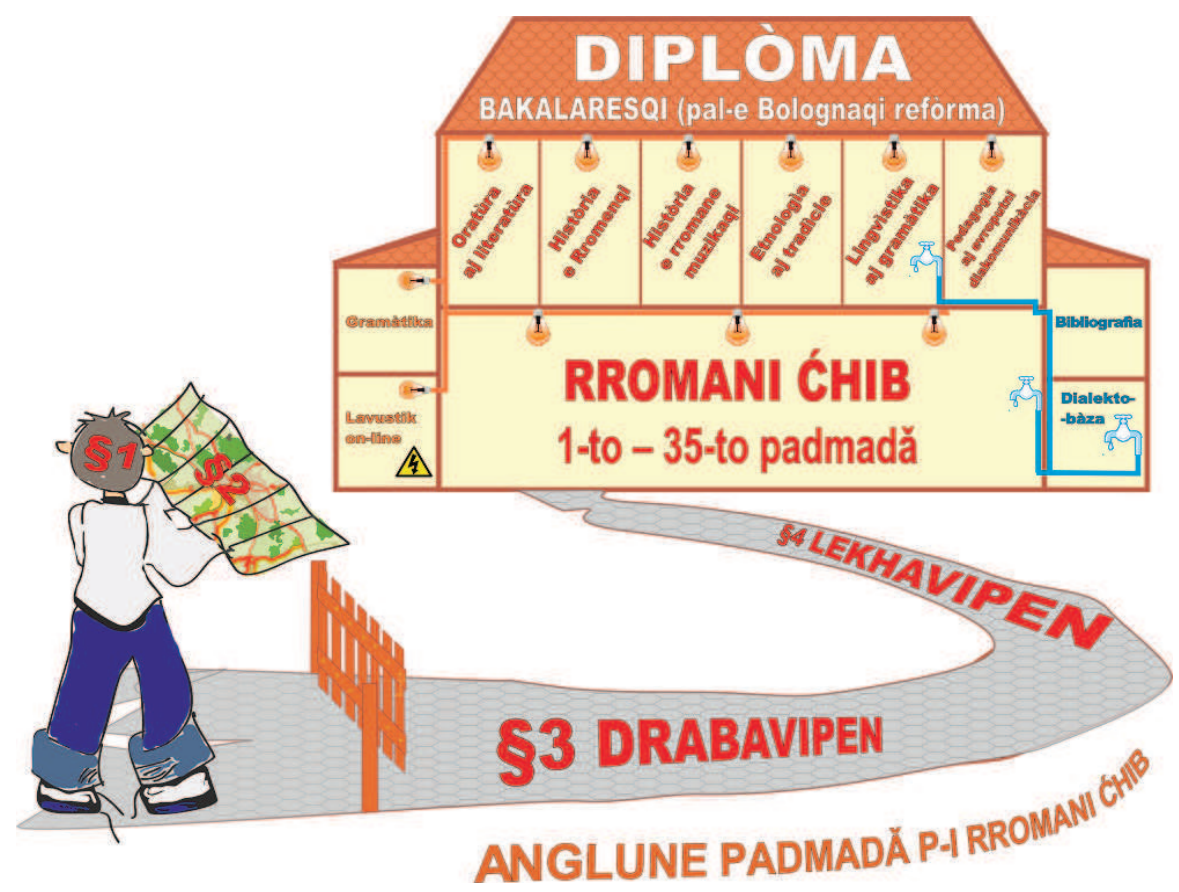

Figure1: Structure of the R.E.D.-RROM portal. 


\section{Structure of the portal}

The course is built up in three main parts:

- an introduction, for both native speakers and beginners,

- one course in Rromani language, made up of 35 units,

- a level devoted to Rromani culture.

The culture part is divided into six topics, namely:

- Rromani literature,

- history,

- history of Rromani music,

- ethnology,

- linguistics,

- teaching and European communication.

The purpose of the culture part is definitely to provide for the student with reliable data in the concerned fields but first of all to train the student using Rromani as a language of elaborated and intellectual exchanges, beyond everyday home speech.

\section{Preliminary steps}

The present course is basically intended for University students preparing the Bologna type bachelor's degree (three first years of higher studies) but it was devised in an everyday vocabulary so that any person with a mid-level education, average intelligence and above all a real wish to learn may master it and enjoy doing so.

The preliminary part of this course is divided into four steps $(\S 1-4$ in the figure 1). The first step about the method $(\S 1)$ consists in positioning the student within the dialect system of Rromani - first of all answering the crucial question of what a dialect is and what the structure of Rromani is from this point of view. The answer is given in the second step the socalled "dialect issue" $(\S 2)$ with the aid of several games based in dialects of each navigation language aimed at teaching the student this key-notion.

For example, the isogloss games, never existed before, have been created thanks to the Smallcodes' technologies. To understand the isogloss crossing between two dialects, the student tries to draw a line correctly 
between diasynonyms. In figure 2, we see the result of the question about two dialectal variants in Bulgarian, дядо and дедо. The zigzag line is drawn by the student and the curved one is programed as the right answer in the system.



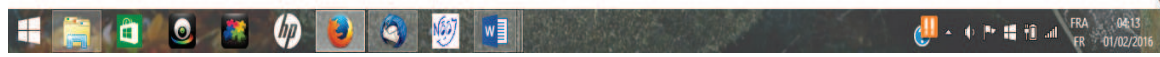

Figure 2: An isogloss game with Bulgarian variants

When the student is already familiar with this notion, s/he is invited to learn how to read in Rromani in the third step ( $\S 3$ drabavipen that means "reading" in Rromani), with the following alternative: a short normative approach - with a scheme summarizing the equivalences between the Rromani letters and the navigation languages' ones, or an in-depth explanation of the reading rules together with their rationale.

The fourth step is the acquisition of writing skills ( $\$ 4$ lekhavipen that means "writing" in Rromani): the student is first invited to download the executive driver EuroUniv, which allows him to write in all dialogue boxes in any of the Latin based scripts of Europe - used to write all the 52 European languages with a Latin alphabet, including Rromani. After a short explanation, the student reaches a series of words and short sentences which s/he is supposed to listen to as uttered by various speakers and then write down 
in appropriate dialogue boxes as a training to write Rromani. The student hears the same sentence in various pronunciations but $\mathrm{s} /$ he has to type one single writing. In other cases there is a difference in the words and $\mathrm{s} / \mathrm{he}$ has to write two different renderings (for example if one notion is expressed by two words - similar like pani/paj "water" or not like zivel/trail "s/he lives").

\section{Course in Rromani language}

The real course in Rromani language begins after the preliminary steps with a series of 35 lessons, called padmadă "steps, stages". The axis of each lesson is a short dialogue which is given in the four "roof dialects" of the Rromani language and played as a short scene in a video-clip. Special emphasis is put on the spoken language, because all people around us speak much more than they write and the first natural contact with a language takes place though hearing. The present approach is therefore the opposite of most teaching methods which first introduce the written/ read word and only later the spoken communication - resulting usually in an insufficient mastery of listening skills. In order to develop these skills in spite of the differences of pronunciation, every video-clip itself is available with vocal dubbing in each of the four Rromani dialects, to be selected with one of the buttons (figure 3 ) visible as the student enters the language course, accompanied by default by subtitles in the same dialect.

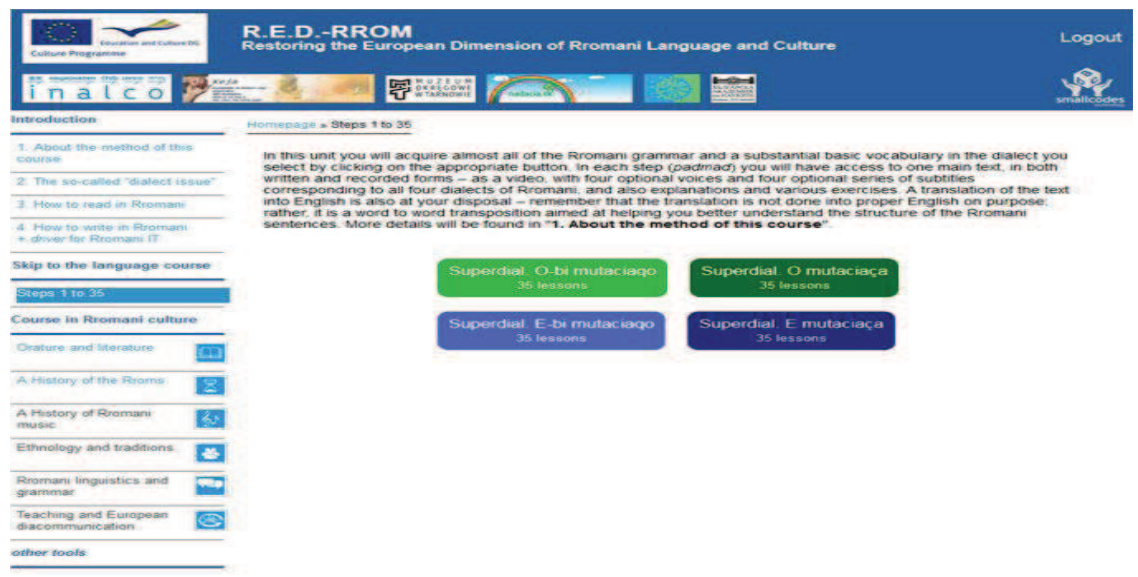

Figure 3: Setting buttons to select a dialect (bi-mutaciaqo means "without mutation, mutaciaça "with mutation") 
In addition, the student may change the dialect of the subtitles by a click on one of the three other dialects' buttons differing from the dialect of hearing. Through combining the dialect of hearing and the dialect of the subtitles, the student gets used to the dialectal variation and learns how to understand all dialects while using actively his own or the one he has chosen at the beginning of the course.

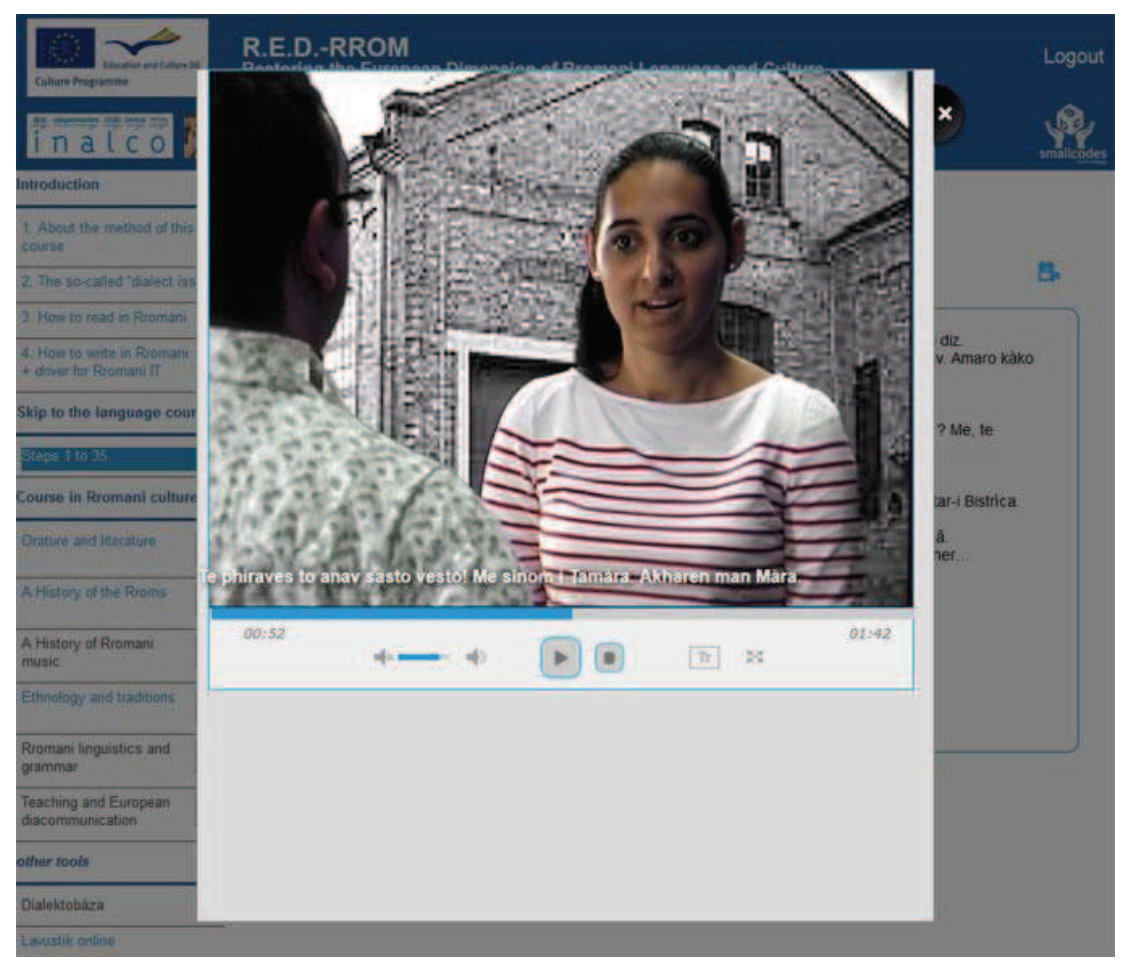

Figure 4: Video-clip for language course

The student is supposed to listen to the video-clip, with the help of the translation and of the grammar explanations given under the text itself, as many times as $\mathrm{s} / \mathrm{he}$ understands naturally the replicas of the dialogue. The Rromani syntax is not the same as the syntax of other languages and we reduce therefore to a minimum the use of translations in navigation languages, because this would lead the student to transfer involuntarily the navigation languages' structures into Rromani. It is much more advisable to encourage him/her think naturally in Rromani. 
Language teaching relies usually on two methods: immersion imitating the natural conditions in which children learn and analytic which details the functioning of the elements in the text. Our approach is a compromise between the two, with a series of video-clips devised to be as close to real life as possible and a minimum of grammar, in order to make more easy the understanding of the linguistic structure of Rromani. Grammar is presented in a simplified form, with no technical words reminding of school lessons, but with expressions coined ad hoc to explain the sentence building. The grammar explanations given with the lessons in the respective navigating languages are only a kind of compass making shorter the way between hearing and understanding. There is another grammar in the course, more complete and descriptive, and the link symbol GR (meaning grammar) sends to the appropriate passage when useful.

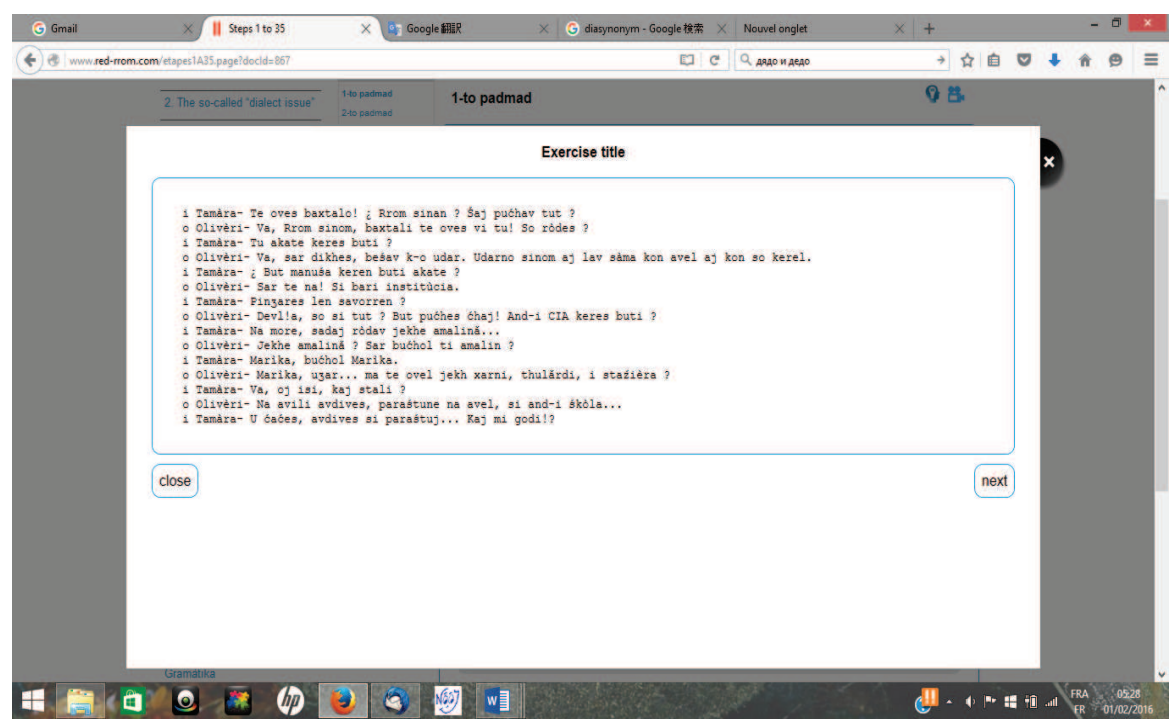

In addition to the centre of every padmad "step", represented by the video-clip, dubbing and subtitles with translation and explanations in the navigation languages, the student has at his/her disposal various exercises. The first and most important one is the half-hidden and hidden sentences: the student opens the dialogue of the exercise, which is the text of the padmad, and reads aloud the first sentence, then he clicks and one part of the 
sentence gets hidden $-\mathrm{s}$ /he has to repeat if by heart with the help of the remaining letters and a second click totally hides the sentence, which s/he is then supposed to repeat by heart, and so on with the successive replicas.

Figure 5: Exercise with half-hidden sentences and its original tes

The other exercises belong to several types, mainly matching of clauses or phrases, written and spoken, as described in the title of the given exercise.

Every padmad provides also the student with reading passages of various kinds, readable with the support of the readalong system: adapted texts from newspapers and periodicals, biographies of significant Rroms of the past, curiosities of the Rromani vocabulary, jokes and anecdotes, songs with karaoke, fragments of non-Rromani literatures translated (or adapted) into Rromani, information about peripheral varieties - mainly those in use among Sinti and Kalo, for example...

\section{Course in Rromani Culture}

Once a solid proficiency of Rromani language is acquired, the student is invited to skip to the main aspects of Rromani culture, presented through six panels: Rromani orature and literature, history of the Rroms, history of Rromani music, ethnology and traditions, linguistics and grammar, teaching and European diacommunication

\section{Rromani orature and literature}

After a few introductory and theoretical articles devoted to the main aspects of this domain, the panel supplies 99 reading passages with readalong support and presented in order of increasing difficulty in a table of 99 boxes for each of the genres at stake: folk tales, lyrics of songs, ethno-texts, poems, proses, dialogs (theatre), articles and essays as well as translations from other literatures.

The student can view the title of each text with a mouse-over on the corresponding box and s/he then has access to it by a click. S/he can listen to the text in two playback options for each, namely:

- One accompanied by the readalong support - namely in audio form, read by the author him/herself, whenever it was possible, or by an actor in other cases, if $\mathrm{s} /$ he activates the readalong track. 
- The other one audio only, without readalong, if the audio only command is operated.
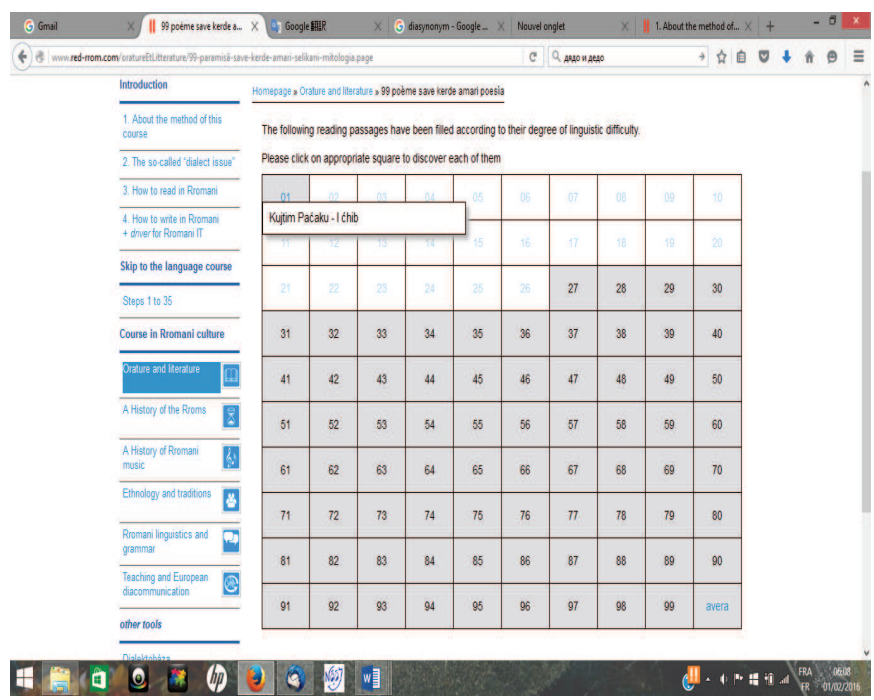

Figure 6: Rromani poem in each of 99 boxes

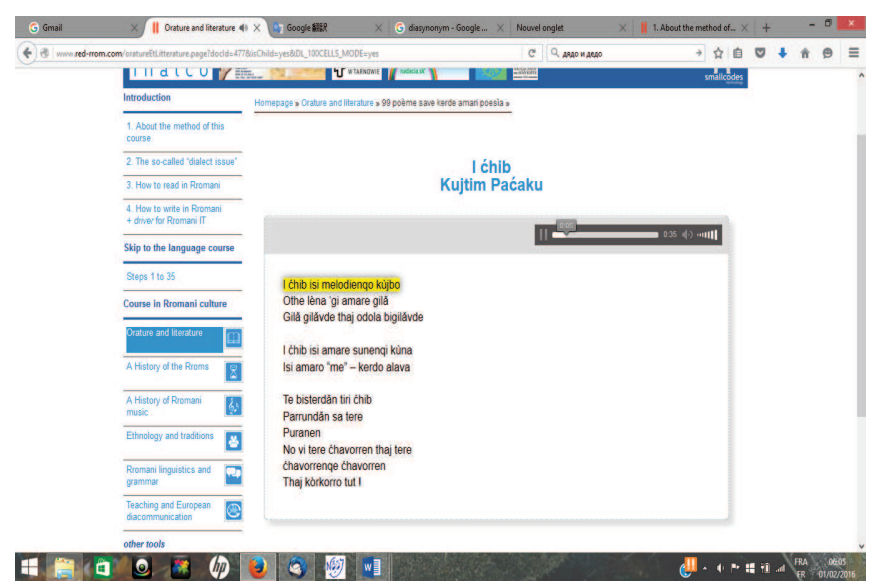

Figure 7: The readalong system shows the sentence read by author with highlight (see the first sentence)

The student is then supported by a pop-up system, which provides him/her with the explanation of the "difficult words" in the text. In this case, the "difficult words" are highlighted in colour and a pop-up with 
the corresponding explanations or translations appears, when hovering the mouse over the word. These "difficult words" are mainly borrowings of the author to local languages, some very local dialect forms, archaisms and neologisms belonging to his/her own vocabulary.

Further material is available by a click on the last box of the board. Each reading passage is followed by a few questions the student is invited to answer. The spellchecker system helps him/her to correctly write his/ her text of reply.

\section{History of the Rroms}

This panel is presented in the various modalities namely: documentary movies, audios, texts, pdf of the texts, "resource centre", and chronology.

\subsection{Documentary movies}

A series of 17 documentary movies covering a wide scope in both terms of time and space: since ancient India to present time Brazil - these movies start when one click on the "camera" icon 4 . In this panel, the Rroms' History is divided mainly according to the various empires and culturo-political areas the Rroms went through or lived in. Just like in the case of the video-clips of Rromani language teaching, each of them is available with vocal dubbing in each of the four Rromani dialects, to be selected with the tab - as one may see in the figure 8 .

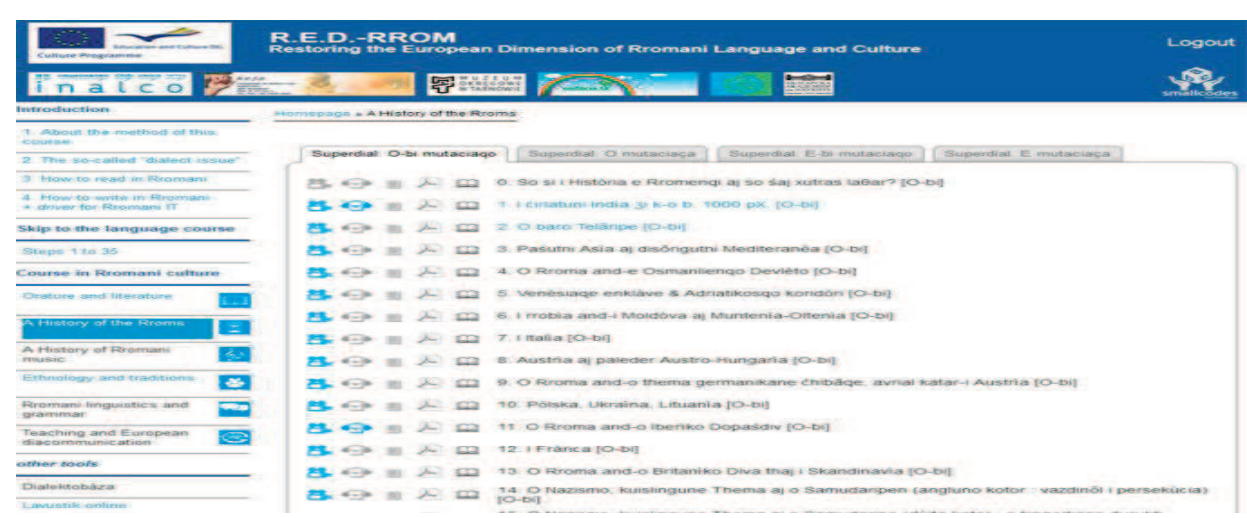

Figure 8: Extract of the Rroms' History panel with dialects' tabs of hearing 
The movies are accompanied by default by subtitles in the same dialect - which the student may change by a click on one of the smaller buttons under the button of the voice dubbing, in the way indicated on the figure 9 (the upper arrow shows the selection of the dialect to be listen to in audio, whereas the lower arrow indicates the selection of the subtitles dialect).

These movies give a bird's eye view of the subject under discussion.



Figure 9: Selecting different dialects of hearing and the subtitles of documentary movies (a/śun means "listen!")

\subsection{Audios}

A series of longer and more detailed texts, available only in written, with two options of reading, namely:

- one with readalong support - if one clicks on the "earphones with down arrow" icon $\nabla$,then on the "earphones with text sheet" icon for each of the text sections: Dand one activates then the readalong track.

- the other audio only, without readalong, if the audio only command is operated. The student is then supported by a pop-up system, which provides him with the explanation of the "difficult words" in the text. In this case, the "difficult words" are highlighted in colour and a pop-up with 
the corresponding explanations and translations appears, when hovering the mouse over the word. These "difficult words" are mainly names of historical places and people, international modern vocabulary and scholarly terminology related to the given period and place (names of institutions, tools, garments, liturgical objects, terms related to buildings or vehicles and so on).

\section{3. "Resource centre"}

A "resource centre" containing a bibliography of publications related to the subject of the given chapter and reproductions of pictures and documents in the best possible resolution for any possible further use.

There are also sometimes on-line books, entire or not.

\subsection{Chronology}

The panel is completed by a two dimension zoomable chronology gathering the 1.000 most salient events of Rromani history.

\section{History of Rromani music}

A dozen of chapters cover the main kinds of Rromani music, with the addition of a chapter devoted to the pre-islamic music of India. Each chapter consists in a text available in written on the screen with two options of reading namely one with readalong support and one with access to explanation of "difficult words" by mouse hovering about them. Yet in this panel, texts are given in only one dialectal form in order to present a wider range of Rromani local forms - which wouldn't have appeared if we got stuck to the four roof dialects.

The last chapter of this panel consist in a choice of 99 Rromani evergreens prepared for karaoke singing.

A scheme depicting the evolution and kinship of songs within every genre (when available) appear by click on the icon $\approx$ and a series of links to illustrative video-clips are added to this texts as well as URL of available on-line interesting soundtracks. 
As in the History panel, a pdf of the text of the chapter is available for download and printing.



Figure 10: Panel of the History of Rromani music with diverse icons

\section{Ethnology and traditions}

This panel consists in an introduction to some key aspects of general ethnology and ethnological methodology, a series of articles devoted to Rromani traditions in the section Kulturàlo rromologìa (as indicated in the Content table), some elements of non-Rromani traditions in the section Kulturàlo gazologìa (mainly when relevant to a better understanding of Rromani traditions) and finally Kulturàlo rromografia, with a critical analysis of ethnological studies led by non-Rroms in the Rromani field.

All these texts are presented on the one hand with readalong support - in one vernacular form of Rromani, and on the other hand with access to the explanation of "difficult words" when hovering the mouse over then. As in the musicology panel, the texts are presented in a single Rromani vernacular form, in general and when available, namely the form of the author or translator, in order to present a wider range of local forms 
of Rromani. Here too there is a pdf to download and print, according to the wish of the student.

\section{Linguistics and grammar}

This panel supplies under the heading "Founding texts" pages of historical significance devoted to Rromani and its evolution. Many inputs in this section are written in majority languages (without readalong device), as written in original, in order to make them accessible also to persons who do not necessarily want to learn Rromani. In some cases they are translated in one or several other languages.

One will find also a descriptive Standard Rromani Grammar (also consultable on digital tablets) and various articles about more focused topics, such as the history of Rromani or some points of sociolinguistics.

\section{Teaching and European diacommunication}

In this panel also, many inputs are written in majority languages (without readalong device), as written in the original, in order to make them accessible to persons who do not necessarily want to learn Rromani. Taking on account the fact that any wide diacommunication starts with an early acquisition of a solid command of the given language by children, it is divided in two parts: one providing didactic material for school classes and extraschool activities in Rromani and another one dealing with crucial topics related to modern Rromani in European societies: the relationship between oral and written Rromani, inherited vocabulary and borrowings, loan-words and loan-translations, terminology and neology, syntax of formal texts and so-called elevated style, clichés and stereotypes in language, language and worldview, evolution of Rromani, various styles, strategies of mutual understanding between Rroms of various dialectal backgrounds and so on.

\section{Additional material}

The Course is completed by five collateral resources:

a) a multilingual on-line dictionary; 
b) a database of dialectal profiles (dialektobàza), allowing the comparison between 250 archetypal sentences exhibiting concrete linguistic facts within one Rromani vernacular or between two different vernaculars;

c) a direct access to the Standard Rromani Grammar;

d) a bibliography of most significant publications in the Rromani domain with a system of browsing by author, title and key-words;

e) a collection of historical quotes about the Rroms, collected in various countries - under the entry Citotèka.

One will find finally a corner with acknowledgments to the various persons and institutions who brought a valuable input to the project and another one with URL of web-sites of Rromani interest.

\section{Conclusion}

The introduction of the R.E.D.-RROM web portal consists of positioning the student within the dialect system of Rromani - first off, answering the crucial question: what a dialect is and how it is the structure of Rromani from this point of view. Then the student immerses themselves in real-life Rromani language through everyday home speech with a videoclip for language lessons. And finally the culture part is aimed at providing the student with reliable data in the concerned areas but first of all for training using Rromani as a language of elaborated and intellectual exchange.

Therefore the methods and the ICT technologies developed by Smallcodes and used to elaborate the R.E.D.-RROM portal would be applicable for other minority languages to make their own IT tool in the future.

\section{References:}

Courthiade, M. (2009 Budapest: Cigány Ház). Morri angluni rromane ćhibăqi evroputni lavustik.

R.E.D.-RROM (Restoring the European Dimension of Rromani Language and Culture). Available at

www.red-rrom.com

Marcellaneous. Available at marcel-online.net 


\begin{abstract}
R.E.D.-RROM is a transnational web portal designed for school teaching of Rromani as the target language, created by Smallcodes with the most recent ICT technologies as the first comprehensive IT learning tool for Rromani. The portal is divided into three macro-sections: introduction, language course, Rromani culture. The whole course is basically intended for university students but it was devised in an everyday vocabulary so that any person with middle education learn from it effectively. The final aim of the portal is to demonstrate that Rromani language can be used as a formal and literary exchange language and be considered single language. Therefore students can combine different dialects of audios and of subtitles on this portal, in order to get used to the dialectal variation and notice that they can understand all the dialects. The culture section includes diverse topics such as literature, history, linguistics and European communication, that are all presented in Rromani language.
\end{abstract} learning.

Keywords: R.E.D.-RROM, Rromani language, Smallcodes, ICT technologies, IT

\title{
Biographical statement
}

MARCEL COURTHIADE is the Commissioner of the International Rromani Union for language and language rights and professor of Rromani language and culture in the City INALCO Paris-Sorbonne since 1997. He acquired on the ground everyday practice of Balkan languages since 1973 and researched the development of the Rromani language first in the Balkan Peninsula (he originates from Greece) and then at the European and world wide level. He received his $\mathrm{PhD}$ at the Paris III Sorbonne on the theme "Phonology of Rromani dialects and written diasystem of the Rromani language" (969 pp.). He has published almost 300 scientific papers, of which so far about 80 are on the site www.marcel-online.net. He also works as a co-author and editor of the interactive on line course of Rromani language, literature, history, tradition, linguistics and dialectology, etc ... (www.red-rrom.com - password available on request). He organized a large exhibition "The Rromani language: an Asset for Education and Diversity (56 m length)" in the main hall of the European Council in Strasbourg in 2014 and two years later at the Indian Ministry of Foreign Affairs in New-Delhi. Currently he is involved in preparing the scientific 
and cultural activities marking the 1000 anniversary of the "Baro Telăripe" (the proto-Rroms' deportation from the city of Kannauj (now in U.P.) at the end of 1018).

Email: si2emc@gmail.com

MASAKO WATABE

2012 MGR in Linguistics, INALCO, France, « Description of the Rromani language with the aim of creating a NooJ module ».

2010 Licence in Rromani language, INALCO, France.

1990 Licence in Literature, Waseda University, Japan.

RESEARCH INTERESTS

Description of the Rromani language (morphology, syntax, typology, dialectology),

Development of the NooJ module for Rromani language,

IT resources for languages learning (on-line learning, didactic software, e-dictionaries),

Language Diversity (minority languages and dialectology).

\section{PUBLICATIONS}

«A NooJ module for Rromani language IT tools for Rromani studies », Jubilee publication for Dr. Gheorghe Sarau, Rumania, 2016 (forthcoming).

« NooJ module for Rromani », Formalising natural languages with NooJ, CSP, UK, 2013.

\section{CONFERENCES}

2015 International Conference on Minority Languages, University of Belgrade, Serbia, « R.E.D.-RROM - the first comprehensive IT learning tool for the unified Rromani language $»$.

2014 International Conference, The Rroms and the Rromani language, INALCO, France, «A NooJ module for Rromani - Contribution for R.E.D.-RROM project ».

2012-2014 NooJ International Conference, Italy, Germany, France.

2014 Exhibition, The Rromani language - an Asset for Education 
and Diversity, Council of Europe, France, « NooJ Technology in the Rromani linguistic field ».

Email: masakowatabe@free.fr

\section{CARLO ZOLI}

Email: carlo.zoli@smallcodes.com 